Scientific Review - Engineering and Environmental Sciences (2019), 28 (4), 653-663

Sci. Rev. Eng. Env. Sci. (2019), 28 (4)

Przegląd Naukowy - Inżynieria i Kształtowanie Środowiska (2019), 28 (4), 653-663

Prz. Nauk. Inż. Kszt. Środ. (2019), 28 (4)

http://iks.pn.sggw.pl

DOI 10.22630/PNIKS.2019.28.4.59

\author{
Marcel PAREDES ${ }^{1}$, Tito CASTILLO ${ }^{1}$, Rafaela VITERI ${ }^{2,3}$, \\ Gabriela FUENTES $^{1}$, Elba BODERO ${ }^{1}$ \\ ${ }^{1}$ Faculty of Engineering, Universidad Nacional de Chimborazo \\ ${ }^{2}$ Faculty of Science, Polytechnic School of Chimborazo \\ ${ }^{3}$ Universidad Politécnica de Madrid
}

\title{
Microplastics in the drinking water of the Riobamba city, Ecuador
}

Key words: microplastics, drinking water, water pollution, water distribution system

\section{Introduction}

Plastic is a material that is designed to be durable and economical (Fok \& Cheung, 2015), that's why, it is used for activities such as food, agriculture, medicine, automotive industry, electronics industry, clothing and also in construction and civil works (Dilkes-Hoffman, Pratt, Lant \& Laycock, 2018). Historically the production of plastics each year grows by $9 \%$ (Crawford \& Quinn, 2017a, b). Most plastics (synthetic polymers) are extremely durable and can remain in the environment for billions of years depending on the type of plastic (Chidambarampadmavathy, Karthikeyan \& Heimann, 2017). The use of plastic has become common in drinking water facilities in recent years (Kelley, Stenson, Dey \&
Whelton, 2014), The Ecuadorian Technical Construction Standard recommends the use of rigid vinyl polymer (PVC) for potable water pipes in construction and distribution networks. All plastic to degrade by use and age releases micro plastic fragments (Wright \& Kelly, 2017). Plastic fragments with a diameter less than $5 \mathrm{~mm}$ are commonly referred to as microplastics - MPs (Auta, Emenike \& Fauziah, 2017; Novotna, Cermakova, Pivokonska, Cajthaml \& Pivokonsky, 2019), even when the size in which the MPs can be defined is not clearly defined according to the state of the art (Rodríguez-Seijo \& Pereira, 2017). A person can consume up to 14 plastic particles per day; these daily doses add up to an annual total of more than 4,000 (Rochman et al., 2015). The involuntary intake of this material is potentially harmful, since it has been found that MPs produce anomalous effects in the human gastrointestinal system (Van Cauwenberghe 
\& Janssen, 2014). In addition, it has been proven that MPs absorb toxic chemicals related to cancer and other diseases, and then release them when they are consumed by living beings such as fish and mammals (Chen, Feng \& Wang, 2019).

In a study conducted by the University of New York reported that $83 \%$ of samples of water for human consumption contained MPs in 159 cities around the world. These plastic microfibers are present in the tap water of New York, but these substances have also been found in tap water from Beirut (Lebanon), New Delhi (India), Kampala (Uganda), Jakarta (Indonesia) and Quito (Ecuador) (Kosuth, Wattenberg, Mason, Tyree \& Morrison, 2017). In addition to a total of 259 bottles processed, $93 \%$ showed some sign of contamination MPs (Oßmann, Sarau, Holtmannspötter, Pischetsrieder, Christiansen \& Dicke, 2018). In the studies, Nile red prepared in acetone at $1 \mathrm{mg} \cdot \mathrm{ml}^{-1}$ was used to obtain a concentration of $10 \mathrm{ug} \cdot \mathrm{ml}^{-1}$ (Mason, Welch \& Neratko, 2018). Nile red adsorbs to the surface of plastics, but not to more natural materials, and emits fluorescence at specific wavelengths of light (Erni-Cassola, Gibson, Thompson \& Christie-Oleza, 2017). In Ecuador is not been established how the MPs arrived at the water for human consumption in Quito, but it must be considered that the water sources of this city are mostly superficial: rivers and reservoirs (EPMAPS, 2018). Plastic micro-particles can reach the reservoirs and creeks transported by human activities in their environment or even through the air (Napper \& Thompson, 2016; Kosuth et al., 2017; Rojo-Nieto \& Montoto, 2017; Gasperi et al., 2018). Microplastic are present in all water sources around the world, including ice from Arctic glaciers glaciers (Weis et al., 2015; Wright \& Kelly, 2017) and it has also appeared on the mountain glaciers (Treinish, 2017). But its presence has not been reported yet in the underground sources that feed on the melting of these glaciers. A city near to Quito is Riobamba, located in the Ecuadorian highlands, this city is supplied by underground sources: wells and natural springs of water that come from the thaw of the glaciers of the Chimborazo volcano (Reino Moyón, 2013). The Chimborazo is a high point whose glacier can present a large specific surface to air currents that carry micro-fragments of plastic from the ocean (Oliveira, Almeida \& Miguel, 2019), how temperatures can trap it and then heating can cause the fragments to travel to underground streams of water. Hundred percent of the water distributed in the city comes from underground sources extracted by wells, which is then conducted to the reserves and distributed by means of PVC pipes, however no studies have been conducted to detect the presence of MPs in the water from the Riobamba city. Detecting the presence of MPs in the uptake allows to know if the contamination comes from the underground sources, and detecting the presence of MPs in the distribution networks can indicate if the PVC are generating MPs in the drinking water. That is why the objective of the research is to know the percentage of MPs present in the drinking water distribution networks In both cases, this knowledge constitutes an essential element for the decision making of the bodies in charge of regulating the use of water resources and those that manage drinking water systems, which guarantee water without elements that affect human health. 


\section{Material and methods}

\section{Study area}

The water system of the Riobamba city is supplied by the pumping of groundwater from seven wells located $2 \mathrm{~km}$ from the city. With a flow of $525.301 \cdot \mathrm{s}^{-1}$ and the natural slope called San Pablo, wealth of $249.70 \mathrm{l} \cdot \mathrm{s}^{-1}$, the same that is distributed by gravity to the different points of water supply. Additionally, the city has deep wells of underground water that provide a wealth of water of $212.8 \mathrm{l} \cdot \mathrm{s}^{-1}$, which directly supply the main reservation centres. Table 1 describes the study area with the number of distribution system, names of the networks, distribution area, length

TABLE 1. Study area description

\begin{tabular}{|c|c|c|c|c|c|c|c|c|}
\hline $\begin{array}{l}\text { Name of } \\
\text { distribu- } \\
\text { tion } \\
\text { network }\end{array}$ & $\begin{array}{l}\text { Distri- } \\
\text { bution } \\
\text { system } \\
\text { area } \\
\text { [ha] }\end{array}$ & $\begin{array}{c}\text { Pipes } \\
\text { length } \\
{[\mathrm{km}]}\end{array}$ & $\begin{array}{l}\text { Name of } \\
\text { the re- } \\
\text { serve } \\
\text { form } \\
\text { which it } \\
\text { takes }\end{array}$ & $\begin{array}{l}\text { Number } \\
\text { of tanks }\end{array}$ & $\begin{array}{l}\text { Tank } \\
\text { name }\end{array}$ & $\begin{array}{c}\text { Tank } \\
\text { volume } \\
{\left[\mathrm{m}^{3}\right]}\end{array}$ & $\begin{array}{l}\text { Tank con- } \\
\text { dition }\end{array}$ & Tank location \\
\hline Piscín & 646.85 & 49.58 & Piscín & 1 & A & 2000 & in service & $\begin{array}{c}\text { Piscín } \\
\text { neighbourhood }\end{array}$ \\
\hline $\begin{array}{l}\text { San José } \\
\text { De Tapi }\end{array}$ & 306.46 & 76.23 & $\begin{array}{l}\text { San José } \\
\text { De Tapi }\end{array}$ & 1 & A & 2000 & in service & $\begin{array}{c}\text { Prados del Norte } \\
\text { neighbourhood }\end{array}$ \\
\hline \multirow{2}{*}{$\begin{array}{l}\text { Yaru- } \\
\text { quíes }\end{array}$} & \multirow{2}{*}{458.05} & \multirow{2}{*}{30.49} & \multirow{2}{*}{ Yaruquíes } & 0 & A & 0 & $\begin{array}{l}\text { without } \\
\text { service }\end{array}$ & \multirow{2}{*}{$\begin{array}{c}\text { Yaruquíes } \\
\text { neighbourhood }\end{array}$} \\
\hline & & & & 1 & B & 1000 & in service & \\
\hline \multirow[b]{2}{*}{$\begin{array}{l}\text { El Trata- } \\
\text { miento }\end{array}$} & \multirow[b]{2}{*}{168.24} & \multirow[b]{2}{*}{46.47} & $\begin{array}{l}\text { Trata- } \\
\text { miento }\end{array}$ & 1 & A & 1000 & in service & $\begin{array}{c}\text { Tratamiento } \\
\text { neighbourhood }\end{array}$ \\
\hline & & & $\begin{array}{l}\text { Cola } \\
\text { Santa } \\
\text { Anita } \\
\end{array}$ & 0 & A & 0 & $\begin{array}{l}\text { without } \\
\text { service }\end{array}$ & $\begin{array}{c}\text { Santa Anita } \\
\text { neighbourhood }\end{array}$ \\
\hline \multirow{2}{*}{$\begin{array}{l}\text { El Re- } \\
\text { creo }\end{array}$} & \multirow{2}{*}{191.51} & \multirow{2}{*}{55.18} & \multirow{2}{*}{ El Recreo } & 1 & A & 500 & in service & \multirow{2}{*}{$\begin{array}{c}\text { Primero de Mayo } \\
\text { neighbourhood }\end{array}$} \\
\hline & & & & 1 & $\mathrm{~B}$ & 500 & in service & \\
\hline \multirow{2}{*}{$\begin{array}{l}\text { Maldo- } \\
\text { nado }\end{array}$} & \multirow{2}{*}{621.34} & \multirow{2}{*}{126.88} & \multirow{2}{*}{$\begin{array}{l}\text { Maldo- } \\
\text { nado }\end{array}$} & 1 & A & 2500 & in service & \multirow{2}{*}{$\begin{array}{l}\text { road to Guano } \\
\text { city }\end{array}$} \\
\hline & & & & 1 & $\mathrm{~B}$ & 2500 & in service & \\
\hline \multirow{5}{*}{ Saboya } & \multirow{5}{*}{907.25} & \multirow{5}{*}{172.3} & \multirow{5}{*}{$\begin{array}{c}\mathrm{La} \\
\text { Saboya }\end{array}$} & 1 & $\mathrm{~A}$ & 1000 & in service & \multirow{5}{*}{$\begin{array}{c}\text { Saboya Civil } \\
\text { neighbourhood }\end{array}$} \\
\hline & & & & 1 & $\mathrm{~B}$ & 1000 & in service & \\
\hline & & & & 1 & $\mathrm{C}$ & 1000 & in service & \\
\hline & & & & 1 & $\mathrm{D}$ & 2000 & in service & \\
\hline & & & & 1 & $\mathrm{E}$ & 2000 & in service & \\
\hline \multirow{2}{*}{$\begin{array}{l}\text { San } \\
\text { Martin } \\
\text { De Vera- } \\
\text { nillo }\end{array}$} & \multirow[b]{2}{*}{944.64} & \multirow[b]{2}{*}{145.82} & \multirow{2}{*}{$\begin{array}{l}\text { San Mar- } \\
\text { tin De } \\
\text { Veranillo }\end{array}$} & 0 & A & 0 & not build & \multirow{2}{*}{$\begin{array}{c}\text { San Martin } \\
\text { De Veranillo } \\
\text { neighbourhood }\end{array}$} \\
\hline & & & & 0 & B & 0 & not build & \\
\hline \multirow{2}{*}{$\begin{array}{l}\text { El Car- } \\
\text { men }\end{array}$} & \multirow[t]{2}{*}{611.61} & \multirow[t]{2}{*}{101.68} & \multirow{2}{*}{$\begin{array}{c}\text { El } \\
\text { Carmen }\end{array}$} & 1 & A & 1500 & in service & \multirow{2}{*}{$\begin{array}{c}\text { Balboa city } \\
\text { neighbourhood }\end{array}$} \\
\hline & & & & 1 & B & 2000 & in service & \\
\hline
\end{tabular}


of pipes, number of tanks, volume, and conditions.

\section{Samples selection}

To identify the sampling points, we use the water sources, reserves, distribution networks and hydrants for drinking water supply, the company Municipal Drinking Water and Sewerage Company of Riobamba city (EP EMAPAR), which provided information and subsequently, the corresponding route was carried out evaluating a total of 62 sampling points (Table 2). This networks represent the totality of the Riobamba city. Figure 1 represents the urban plan of the Riobamba city, with the areas of the nine distribution networks, the location of the tanks, distribution networks and hydrants.

TABLE 2. Sampling points description

\begin{tabular}{|l|c|}
\hline Description & Number of samples \\
\hline $\begin{array}{l}\text { Sources of water } \\
\text { collection (A-S) }\end{array}$ & 20 \\
\hline Reserves (A-N) & 15 \\
\hline $\begin{array}{l}\text { Distribution network } \\
\text { (A-Q) }\end{array}$ & 18 \\
\hline Hydrants (A-I) & 9 \\
\hline
\end{tabular}

For the taking of samples, we use the provisions of the Ecuadorian standardization regulations NTE INEN 1108:2014, which states that "The sampling for the microbiological, physical, and chemical analysis must be carried out according to the standardized methods for drinking and residual water (Standard Methods No. 1060)". Each sample was collected by letting the water circulate from the faucet tap for 1 minute before filling a bottle of HDPE from 1,000 $\mathrm{ml}$ to the point of overflow; While the tap water was running, the bottle for the water sample was homogenized twice before being filled for the third time and sealed.

\section{Samples analysis}

For the analysis of the samples, the methodology was proposed by Erni-Cassola et al. (2017), Maes, Jessop, Wellner, Haupt and Mayes (2017), Mason et al. (2018). A field tab is needed for each water sample, a way to facilitate the survey. In a laminar flow chamber to avoid altering the samples, pouring $250 \mathrm{ml}$ of water by vacuum filtration through a cellulose filter $37 \mathrm{~mm}$ in diameter with a pore size of $2-4 \mu \mathrm{m}$, the filter was subsequently placed in a Petri dish and adding $1 \mathrm{ml}$ of Rose Bengal pigment, based on selective fluorescence. Bengal Rose adsorbs to the surface of plastics, but not to more natural materials, and emits fluorescence at specific wavelengths of light. With the obtained samples we worked in a laminar flow chamber to avoid the alteration of the samples, pouring $250 \mathrm{ml}$ of water by vacuum filtration through a cellulose filter from $37 \mathrm{~mm}$ in diameter with a pore size of $2.5 \mu \mathrm{m}$, later the filter was placed in a Petri dish and adding $1 \mathrm{ml}$ of rose Bengal (4,5,6,7-tetrachloro-2', 4', 5', $7^{\prime}$ -tetraiodofluorescein, $200 \mathrm{mg} \cdot \mathrm{l}^{-1}$. After a reaction time of $5 \mathrm{~min}$, it was analysed in a stereoscope (iVu 7000. With 7.1 Mpx) with an integrated camera which facilitated the identification of MPs.

\section{Results and discussion}

A total of 62 sampling points were identified and a sample was analysed for each identified point. The classification of plastic particles was considered in the 


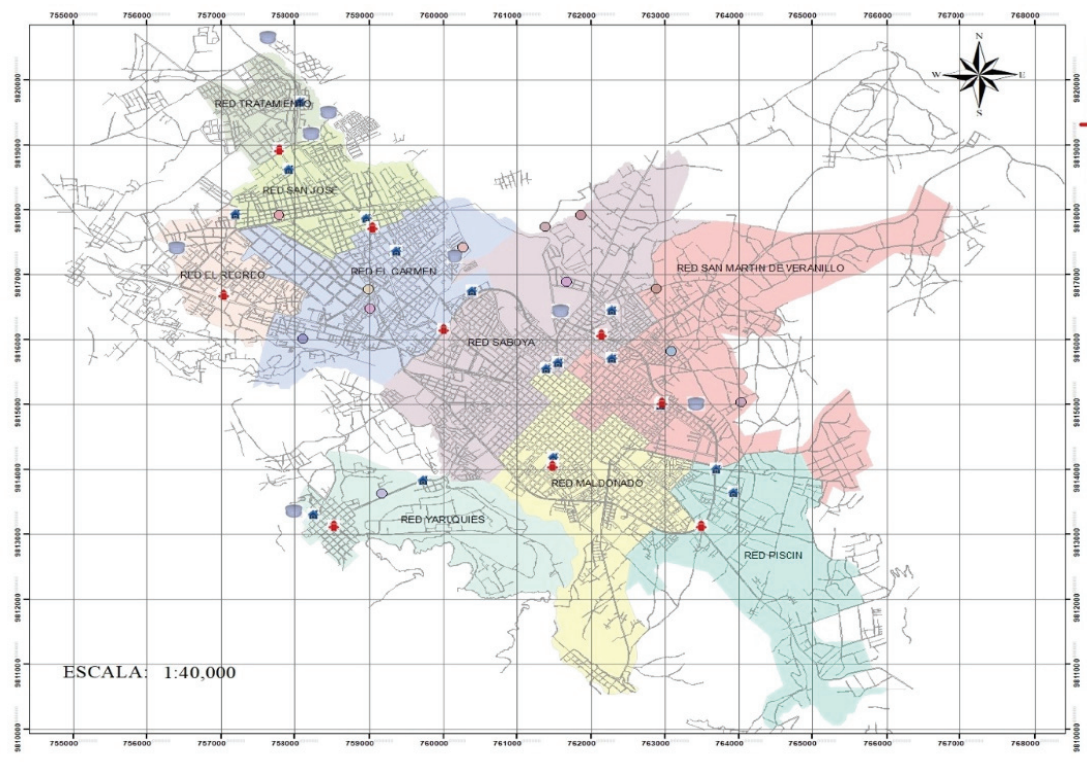

Symbology

는 hydrant

슬 Network point

FIGURE 1. Map of sampling points in the Riobamba city

study (Rojo-Nieto \& Montoto, 2017) establishing the size of the microplastics in the range from $5 \mathrm{~mm}$ to $1 \mu \mathrm{m}$. When analysing the sources of water supply for the city of Riobamba, 20 samples were obtained, including 19 deep wells of groundwater and one natural spring. The same ones that were symbolized in letters from A to S. Finding microplastics in three of the analysed samples that are $\mathrm{B}, \mathrm{C}$ and $\mathrm{G}$, as shown in Figure 2, the same ones that were taken at the exit of the wells in the temporary storage tanks.

\section{Sources of water collection}

Sources B, C and G represent 15\% of the analysed samples, which contain microplastic fibers from three to two field units per $250 \mathrm{ml}$ of filtered water as indicated in Figure 3. However, none exceed the index presented by Rochman

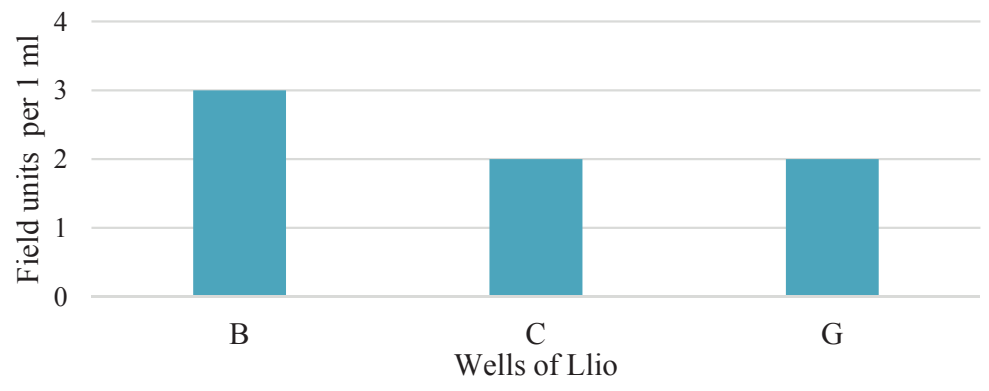

FIGURE 2. Microplastics in underground water sources (wells and sheds) 


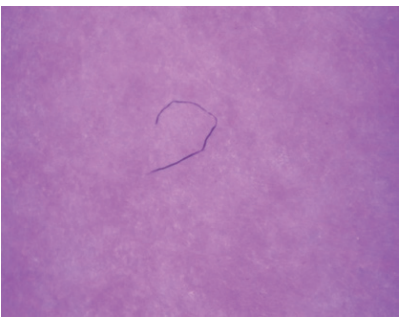

Sample source B with $3.36 \mathrm{~mm}$ fiber

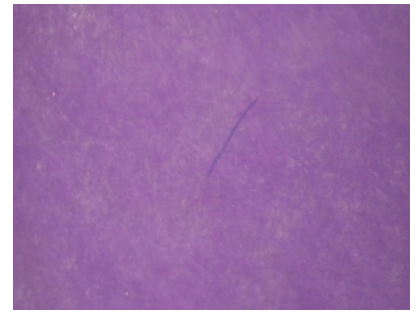

Sample source C with $1.95 \mathrm{~mm}$ fiber

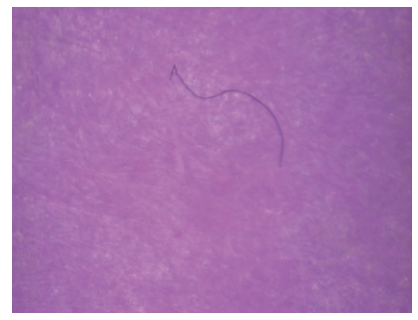

Sample source G with $4.32 \mathrm{~mm}$ fiber

FIGURE 3. Microplastics fibers of in groundwater source

et al. (2015), where it states that you can consume up to 10 microplastic particles.

\section{Storage tanks}

In the Riobamba city there are 15 drinking water storage tanks, the same ones that by methodology were symbolized in letters from A to N (Fig. 4). Reserves $\mathrm{D}, \mathrm{I}, \mathrm{K}$, and $\mathrm{N}$ represent $26.66 \%$ of the analysed samples, which contain microplastic fibers of 2-1 unit of field for each $250 \mathrm{ml}$ of filtered water of the samples analysed as indicated in Figure 5.

\section{Distribution networks}

With the production of the flow through the deep wells the EP-EMAPAR realizes the distribution for the nine ex- isting networks; taking two samples for each one of the networks, considering high and low levels, that by methodology were symbolized in letters from A to Q (Fig. 6). The distribution networks F and $\mathrm{N}$ represent $11.11 \%$ of the analysed samples, the same ones that contain microplastic fibers in a field unit for each $250 \mathrm{ml}$ of filtered water as indicated in Figure 7.

\section{Hydrants}

In addition, the analysis of the sample taken in a hydrant corresponding to each of the distribution networks, symbolized in letters from A to I (Fig. 8). In hydrants C, D, and I, which represent 33\% of the samples analysed, they contain

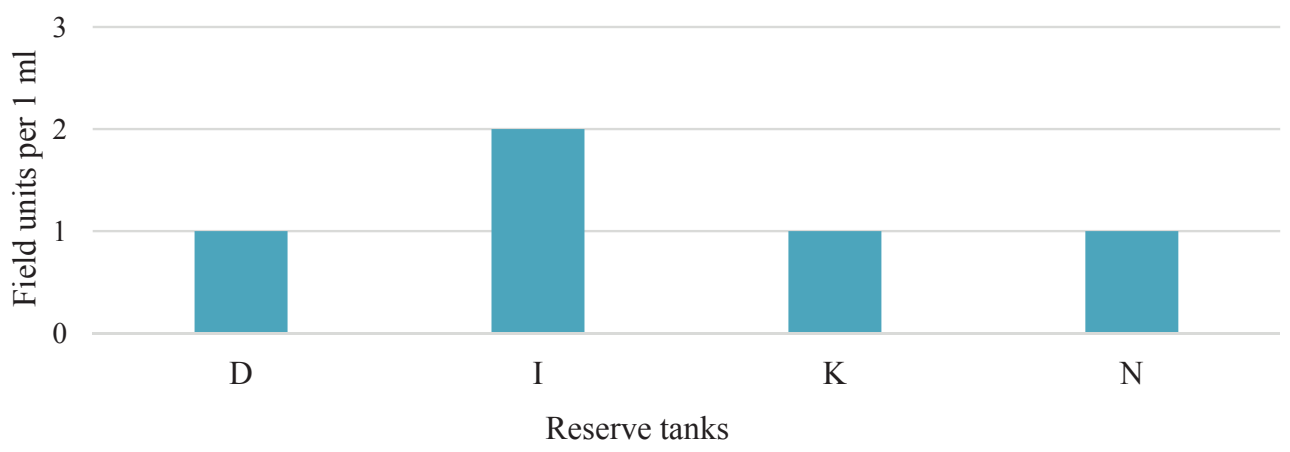

FIGURE 4. Microplastics in the reserves of the Riobamba city 


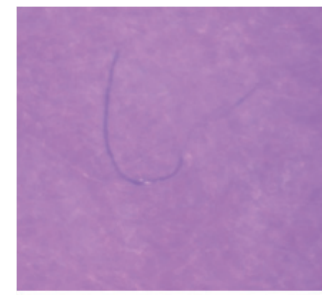

Sample reserve tank D with $4.02 \mathrm{~mm}$ fiber

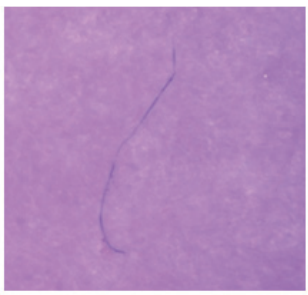

Sample reserve tank I with $4.29 \mathrm{~mm}$ fiber

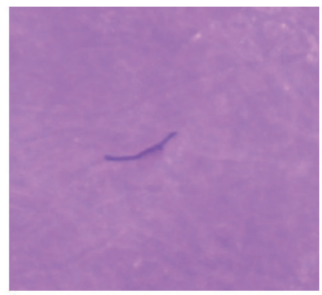

Reserve tank simple K with $0.49 \mathrm{~mm}$ fiber

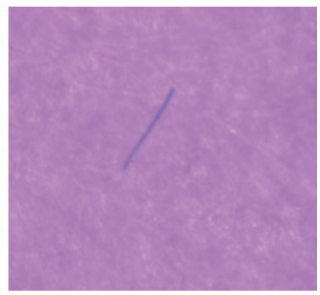

Reserve tank simple N with $1.127 \mathrm{~mm}$ fiber

FIGURE 5. Microplastic fibers of in drinking water reserves in the Riobamba city

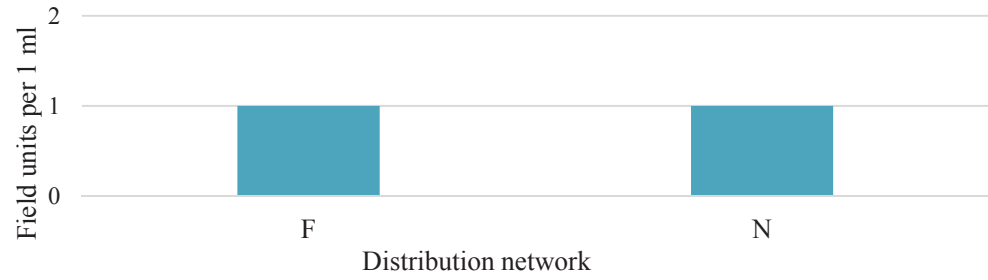

FIGURE 6. Microplastic fibers in distribution networks

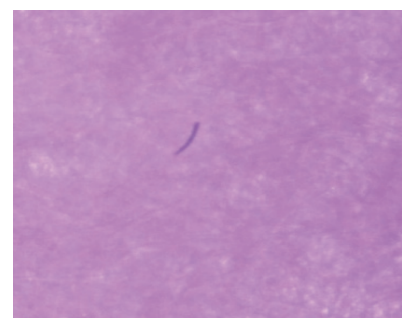

Sample distribution network F wth $0.3067 \mathrm{~mm}$ fiber

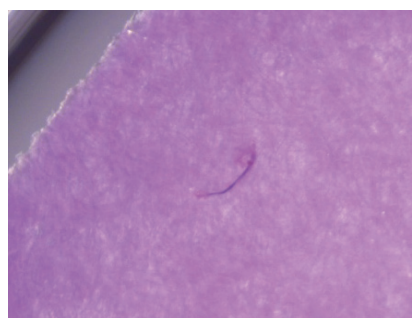

Sample distribution network $\mathrm{N}$ with $0.7005 \mathrm{~mm}$ fiber

FIGURE 7. Microflastic fibers in distribution networks in the Riobamba city

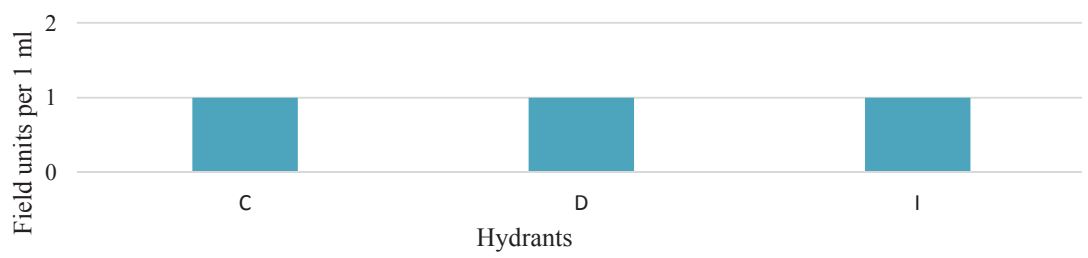

FIGURE 8. Microplastic in hydrants 
microplastic fibers from one field unit per $250 \mathrm{ml}$ of filtered water as indicated in Figure 9. By analysing the samples obtained in each of the elements that make up the city's drinking water supply system, the following results have been obtained Table 3.

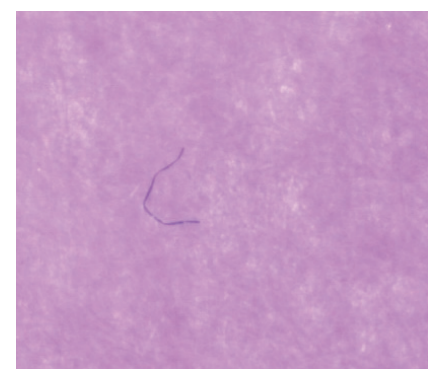

Sample hydrant C with $0.984 \mathrm{~mm}$ fiber

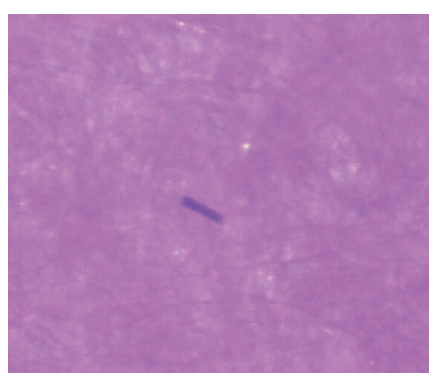

Sample hydrant D with $0.192 \mathrm{~mm}$ fiber
2011); other authors consider the main origin of microplastics in the decomposition and fragmentation of macroplastics (Andrady, 2011) and they are called secondary microplastics. The drinking water and sewerage master plan of the city of Riobamba began in 2011 and ended

FIGURE 9. Microplastic fibers in potable water hydrants in the Riobamba city

TABLE 3. Summary of results obtained in the UNACH Laboratory

\begin{tabular}{|l|c|c|c|}
\hline Description & Number of samples & $\begin{array}{c}\text { Samples with the presence } \\
\text { of microplastics }\end{array}$ & $\begin{array}{c}\text { Samples without the } \\
\text { presence of microplastics }\end{array}$ \\
\hline Water sources & 20 & 3 & 17 \\
\hline Reserves & 15 & 4 & 11 \\
\hline Distribution networks & 18 & 2 & 16 \\
\hline Hydrants & 9 & 3 & 6 \\
\hline Total & 62 & 12 & 50 \\
\hline
\end{tabular}

When comparing the analysed samples vs the samples that present plastic particles it has been obtained that only 12 of the 62 samples present microplastics; what represents that $19 \%$ of the total samples, have presence of microplastics. For some authors the origin of the microplastics is that they are part of the composition of many industrial products, they are called primary microplastics (Cole, Lindeque, Halsband \& Galloway, in 2014, in which the change of asbestos cement pipe was contemplated by PVC pipe in distribution networks and ductile iron pipe. in conductions. The distribution system is constituted by relatively new pipes should not present wear in its elements, therefore, does not generate microplastics. However, according to Crawford and Quinn (2017a) PVC emits toxic chemicals known as phthalates when in contact with water. 


\section{Conclusions}

Based on the results presented in the research, when analysing the 62 samples taken at different points of the drinking water system of the Riobamba city, it is established that in 12 of the samples there are microplastics which represent $19 \%$ of the total samples.

In the absence of standardized parameters of the amount of microplastics allowed in drinking water, it can be concluded that the amount of microplastics found in the study samples is relatively low, considering that in 17 sources of water supply, 11 reserves, 16 points of distribution networks and 6 hydrants no microplastics were found, so $81 \%$ of the samples analysed are free of microplastics.

The possible cause of having found particles of microplastics in three of the tanks of temporary storage of water at the exit of the wells, is due to the presence of greenhouse plastic (LDPE) that was used as a coating before the emergent plan against the fall of volcanic ash, in the temporary storage tanks, it should be noted that by exceeding its useful life (from two to three years) it tends to crystallize and fragment, and may be the source of secondary pollution, since the deterioration of the macroplastics (plastic greenhouse) generates microplastics and therefore can reach each of the units that constitute the drinking water supply system.

When performing a simple sampling at the selected points of each element that constitutes the water supply network, it is not statistically representative, so composite samples should be taken over extended periods of time. In addition, a methodology should be established based on standards that facilitate the identification of the chemical properties of the particles found, and allow them to be compared with standardized results, to ensure that the degree of reliability of the results is adequate. That is why new research should apply other methods for the characterization of microplastics, where you can identify the chemical properties of each particle found. At the same time, the scarce existence of microplastics in the distribution networks can be due to the hardness of the water, which generates a layer inside the PVC pipe, preventing its wear and tear, so future research should analyse the benefits of the Calcareous incrustation in the PVC pipe as a reducer of the amount of microplastics in drinking water. These results are intended to be useful for the different drinking water companies and standardization institutes, which can define a permissible parameter of the amount of microplastics in water for human consumption.

\section{References}

Andrady, A.L. (2011). Microplastics in the marine environment. Marine Pollution Bulletin, 62(8), 1596-1605. https://doi.org/10.1016/ j.marpolbul.2011.05.030

Auta, H.S., Emenike, C.U. \& Fauziah, S.H. (2017). Distribution and importance of microplastics in the marine environment: a review of the sources, fate, effects, and potential solutions. Environment International, 102, 165-176. https://doi.org/10.1016/ J.ENVINT.2017.02.013

Chen, G., Feng, Q., \& Wang, J. (2019). Minireview of microplastics in the atmosphere and their risks to humans. Science of The Total Environment, 135504. https://doi. org/10.1016/J.SCITOTENV.2019.135504 
Chidambarampadmavathy, K., Karthikeyan, O.P. \& Heimann, K. (2017). Sustainable bioplastic production through landfill methane recycling. Renewable and Sustainable Energy Reviews, 71, 555-562. https://doi. org/10.1016/J.RSER.2016.12.083

Cole, M., Lindeque, P., Halsband, C. \& Galloway, T.S. (2011). Microplastics as contaminants in the marine environment: a review. Marine Pollution Bulletin, 62(12), 2588-2597. https:// doi.org/10.1016/j.marpolbul.2011.09.025

Crawford, C.B. \& Quinn, B. (2017a). The biological impacts and effects of contaminated microplastics. In Ch.B. Crawford, B. Quinn (eds) Microplastic Pollutants (pp. 159-178). Elsevier. https://doi.org/10.1016/B978-0-12809406-8.00007-4

Crawford, C.B. \& Quinn, B. (2017b). Plastic production, waste and legislation. In Ch.B. Crawford, B. Quinn (eds) Microplastic Pollutants (pp. 39-56). Elsevier. https://doi. org/10.1016/B978-0-12-809406-8.00003-7

Dilkes-Hoffman, L.S., Pratt, S., Lant, P.A. \& Laycock, B. (2018). The role of biodegradable plastic in solving plastic solid waste accumulation. In S.M. Al-Salem (ed.), Plastics to Energy (pp. 469-505). Norwich, NY: William Andrew. https://doi.org/10.1016/b978-0-12813140-4.00019-4

EPMAPS (2018). Captación - Bienvenido a EPMAPS.

Erni-Cassola, G., Gibson, M.I., Thompson, R.C. \& Christie-Oleza, J.A. (2017). Lost, but found with Nile red; a novel method to detect and quantify small microplastics (20 $\mu \mathrm{m}-1 \mathrm{~mm})$ in environmental samples. Environmental Science and Technology, 51(23), 13641-13648. https://doi.org/10.1021/acs. est.7b04512

Fok, L. \& Cheung, P.K. (2015). Hong Kong at the Pearl River Estuary: A hotspot of microplastic pollution. Marine Pollution Bulletin, 99(1-2), 112-118. https://doi.org/10.1016/ j.marpolbul.2015.07.050

Gasperi, J., Wright, S.L., Dris, R., Collard, F., Mandin, C., Guerrouache, M., Langlois, V., Kelly, F.J. \& Tassin, B. (2018). Microplastics in air: Are we breathing it in? Current Opinion in Environmental Science \& Health, 1, 1-5. https://doi.org/10.1016/j.coesh.2017.10.002
Kelley, K.M., Stenson, A.C., Dey, R. \& Whelton, A.J. (2014). Release of drinking water contaminants and odor impacts caused by green building cross-linked polyethylene (PEX) plumbing systems. Water Research, 67, 19-32. https://doi.org/10.1016/j.watres.2014.08.051

Kosuth, M., Wattenberg, E., Mason, S., Tyree, C. \& Morrison, D. (2017). Synthetic polymer contamination in global drinking water. Orb Media.

Maes, T., Jessop, R., Wellner, N., Haupt, K. \& Mayes, A.G. (2017). A rapid-screening approach to detect and quantify microplastics based on fluorescent tagging with Nile Red. Scientific Reports, 7, 44501. https://doi. org/10.1038/srep44501.

Mason, S.A., Welch, V.G. \& Neratko, J. (2018). Synthetic polymer contamination in bottled water. Frontiers in Chemistry, 6(407), 1-11. https://doi.org/10.3389/fchem.2018.00407

Napper, I.E. \& Thompson, R.C. (2016). Release of synthetic microplastic plastic fibres from domestic washing machines: Effects of fabric type and washing conditions. Marine Pollution Bulletin, 112(1-2), 39-45. https://doi. org/10.1016/j.marpolbul.2016.09.025

Novotna, K., Cermakova, L., Pivokonska, L., Cajthaml, T. \& Pivokonsky, M. (2019). Microplastics in drinking water treatment - current knowledge and research needs. Science of The Total Environment, 667, 730-740. https://doi. org/10.1016/J.SCITOTENV.2019.02.431

NTE INEN 1108:2014. Agua Potable. Requisitos [Drinking water. Requirements]. Instituto Ecuatoriano de Normalización.

Oliveira, M., Almeida, M. \& Miguel, I. (2019). A micro(nano)plastic boomerang tale: a never ending story? TrAC Trends in Analytical Chemistry, 112, 196-200. https://doi. org/10.1016/J.TRAC.2019.01.005

Oßmann, B.E., Sarau, G., Holtmannspötter, H., Pischetsrieder, M., Christiansen, S.H. \& Dicke, W. (2018). Small-sized microplastics and pigmented particles in bottled mineral water. Water Research, 141, 307-316. https:// doi.org/10.1016/J.WATRES.2018.05.027

Reino Moyón, S.J. (2013). Estudio del as Aguas Subterráneas de la Ciudad de Riobamba y sus Zonas de Influencia: Linea Base [Study on the underground waters of the city of Riobamba and its influence zones]. Riobamba: 
Escuela Superior Politécnica de Chimborazo. Retrieved from: http://dspace.espoch.edu. ec/handle/123456789/2501

Rochman, C.M., Tahir, A., Williams, S.L., Baxa, D.V., Lam, R., Miller, J.T., Teh, F.C., Werorilangi, S. \& Teh, S.J. (2015). Anthropogenic debris in seafood: plastic debris and fibers from textiles in fish and bivalves sold for human consumption. Scientific Reports, 5(14340), 1-10. https://doi.org/10.1038/srep14340

Rodríguez-Seijo, A., Pereira, R. (2017). Morphological and physical characterization of microplastics. Comprehensive Analytical Chemistry. Elsevier, 75, 49-66.

Rojo-Nieto, E. \& Montoto, T. (2017). Basuras marinas, plásticos y microplásticos: orígenes, impactos y consecuencias de una amenaza global [Marine, plastic and microplastic wastes: origins, impacts and consequences of a global threat]. Madrid: Ecologistas en Acción.

Treinish, G. (2017). The mystery of the blue microplastic fiber. National Geographic Blog. Retrieved from: https://blog.nationalgeographic.org/2017/06/13/the-mystery-of-theblue-microplastic-fiber/

Van Cauwenberghe, L. \& Janssen, C.R. (2014). Microplastics in bivalves cultured for human consumption. Environmental Pollution, 193, 65-70. https://doi.org/10.1016/ j.envpol.2014.06.010

Weis, J., Andrews, C.J., Dyksen, J.E., Ferrara, R.A., Gannon, J.T., Laumbach, R. J., Young, L. (2015). Human health impacts of microplastics and nanoplastics. Public Health Standing Committee NJDEP Science Advisory Board.

Wright, S.L. \& Kelly, F.J. (2017). Plastic and human health: a micro issue? Environmental Science and Technology, 51(12), 6634-6647. https://doi.org/10.1021/acs.est.7b00423

\section{Summary}

Microplastics in the drinking water of the Riobamba city, Ecuador. The city of Riobamba captures for human consumption groundwater from melting glaciers, from seven wells in the foothills of the Chimborazo volcano. The objective is determine the percentage of existing microplastics in drinking water distribution system. Sixty two samples were collected, analysed with a cellulose filter and Nile red dye. Then observed in a stereoscope, obtaining presence in 12 samples of the 62 analysed. The results of the analysis show that there is a $19 \%$ presence of microplastics.

\section{Authors' address:}

Marcel Paredes

(https://orcid.org/0000-0002-3762-9633)

Tito Castillo

(https://orcid.org/0000-0002-3472-3456)

Gabriela Fuentes

(https://orcid.org/0000-0001-6088-5750)

Elba Bodero

(https://orcid.org/0000-0003-3807-5203)

Universidad Nacional de Chimborazo

Av. Antonio José de Sucre, Km 11⁄2, 060150

Riobamba

Ecuador

e-mail: marcelparedes@unach.edu.ec

Rafaela Viteri

(https://orcid.org/0000-0002-7901-7360)

Polytechnic School of Chimborazo

south Panamericana Sur, Km 11⁄2, 060155

Riobamba

Ecuador

Universidad Politécnica de Madrid

Ramiro de Maeztu 7, 28040 Madrid

España 